\title{
A morte de Odin? As representações do Ragnarök na arte das Ilhas Britânicas (séc. X)
}

Johnni Langer

\section{OpenEdition}

\section{Journals}

\section{Edição electrónica}

URL: http://journals.openedition.org/medievalista/812

DOI: $10.4000 /$ medievalista.812

ISSN: 1646-740X

\section{Editora}

Instituto de Estudos Medievais - FCSH-UNL

Edição impressa

Data de publição: 1 Janeiro 2012

\section{Refêrencia eletrónica}

Johnni Langer, «A morte de Odin? As representações do Ragnarök na arte das Ilhas Britânicas (séc. X) », Medievalista [Online], 11 | 2012, posto online no dia 26 fevereiro 2014, consultado no dia 30 abril 2019. URL : http://journals.openedition.org/medievalista/812 ; DOI : 10.4000/medievalista.812

(C) IEM 


\section{Revista ISSN 1646-740X}

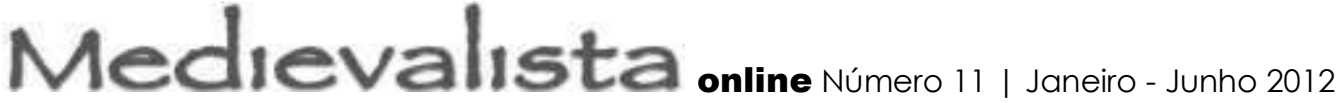

Título: A morte de Odin? As representações do Ragnarök na arte das Ilhas Britânicas (séc. X). Autor(es): Johnni Langer

Enquadramento Institucional: NEVE, Núcleo de Estudos Vikings e Escandinavos, Universidade Federal do Maranhão

Contacto: johnnilanger@yahoo.com.br

Fonte: Medievalista [Em linha]. №11, (Janeiro - Junho 2012). Dir. José Mattoso. Lisboa: IEM.

Disponível em: http://www2.fcsh.unl.pt/iem/medievalista/ ISSN: 1646-740X

\section{Resumo}

Nosso estudo pretende refletir sobre as representações imagéticas do Ragnarök na área britânica durante o final da Alta Idade Média. As principais fontes são imagens esculpidas em cruzes, esculturas tumulares e relevos em blocos. Como principal metodologia, analisaremos as representações em confronto com as fontes literárias islandesas e as imagens disponíveis na área escandinava durante o período viking, especialmente na ilha de Gotland (permanências, rupturas, variações e reapropriações da cultura visual nórdica). Para referencial teórico, empregamos as idéias de Régis Boyer, Margaret Clunie Ross, Hilda Davidson e John Mckinell, no tocante aos mitos nórdicos. Jérôme Baschet e Jean-Claude Schmitt serão empregados como referencial para análise das imagens no medievo, e Herne Fuglesang para interpretação de imagens nórdicas.

Palavras-chave: Ragnarök, Mitologia Escandinava, Arte Anglo-escandinava,Vikings, Odin. 


\section{Abstract}

Our study aims to reflect on the images of Ragnarök in the British area during the late Middle Ages. The main sources are images carved in crosses, funerary sculptures and reliefs in blocks. As the main methodology, we analyze the representations in comparison with the Icelandic literary sources and the images available in the Scandinavian area during the Viking Age, especially on the island of Gotland (continuities, ruptures, variations and reappropriations of Nordic visual culture). For theoretical framework, we employ the ideas of Régis Boyer, Margaret Clunie Ross, Hilda Davidson and John Mckinell, concerning the Norse myths. Jérôme Baschet and Jean-Claude Schmitt will be used as a reference for analysis of images in the Medieval Period and Herne Fuglesang for interpretation of Nordic images.

Keywords: Ragnarök, Norse Mythology, Anglo-Scandinavian Art, Vikings, Odin.

\section{A morte de Odin? As representações do Ragnarök na arte das Ilhas Britânicas (séc. $X$ )}

Johnni Langer

Em diversas partes do mundo, ocorreram representações sobre o fim dos tempos. Muitas culturas preocuparam-se com o porvir, seja com imagens religiosas, preocupações éticas e morais ou narrativas mitológicas. Entre os povos germânicos da Antiguidade e Medievo, são muito conhecidas as narrativas envolvendo o Ragnarök, o destino dos deuses, preservados essencialmente em fontes literárias da Escandinávia centro-medieval, mas também existem algumas imagens produzidas na Alta Idade Média, cuja relação com as narrativas escritas ainda está muito mal explorada. Nosso intento neste estudo é conceder novas perspectivas para o estudo do tema, baseado na análise das representações do Ragnarök presentes na arte das ilhas britânicas do século X. 


\section{Fontes literárias e historiografia}

O termo Ragnarök significa "consumação dos destinos dos poderes supremos"1, e parece ter significado mais antigo que a outra forma islandesa (sing. ragnarökkr “Crepúsculo dos poderes supremos") e se refere a uma série de acontecimentos que culminariam com a morte dos deuses nórdicos mais importantes e a destruição de parte do universo, após o qual algumas deidades e humanos sobreviveriam em uma nova e renovada ordem cósmica. ${ }^{2}$ A palavra existe somente na poesia éddica, não ocorrendo em nenhuma fonte escrita da Era Viking (793-1066 d.C.). ${ }^{3}$

As principais referências escritas sobre o Ragnarök são passagens da Edda Poética, especialmente os poemas Völuspá 44-66 e Vafprúonismál 44-54. A Völuspá (“profecia da vidente") é encontrada nos manuscritos Codex Regius (GKS 2365 4to, c. 1270) e no Hauksbók Codex (A 544 4to, c. 1310), com algumas variações. É o primeiro poema anônimo do manuscrito Codex Regius e geralmente está inserido nesta ordem nas edições modernas. Contem aproximadamente 66 estrofes escritas no estilo fornyrðislág, cujo conteúdo se refere basicamente às visões de criação e destruição do mundo por uma profetisa, ressuscitada pelo deus Odin $^{4}$ para esta finalidade. ${ }^{5}$ A composição do

\footnotetext{
${ }^{1}$ Outras traduções - Ragnarök: "Julgamento dos poderes". LINDOW, John - Norse mythology. Oxford: Oxford University Press, 2001, p. 254; Ragnarök: “Condenação ou fim dos deuses”, Ragnarökkr: "Trevas ou crepúsculo dos deuses”, BYOCK, Jesse - Glossary of names. The Prose Edda. London: Penguin Books, 2005, p. 172-173.

${ }^{2}$ BOYER, Régis - Ragnarök. Héros et dieux du Nord: guide iconographique. Paris: Flammarion, 1997, p. 125.

${ }^{3}$ CHRISTIANSEN, Eric - The norsemen in the Viking Age. London: Blackwell, 2006, p. 299.

${ }^{4}$ No presente artigo, preferimos conservar o nome das principais divindades, seres e localidades da mitologia nórdica na forma tradicionalmente traduzida para a língua portuguesa e inglesa (Odin, Thor, Loki, Heimdall, Frigg, etc). No caso de fontes literárias e termos pouco usuais, conservamos a grafia no nórdico antigo. Este procedimento foi o mesmo adotado por: BAILEY, Richard - Scandinavian myth on viking-period Stone sculpture in England in BARNES, Geraldine \& ROSS, Margaret Clunie (orgs.) - Old Norse myths, literature and society. Proceedings of the $11^{\text {th }}$ International Saga Conference. Sidney: University of Sidney, 2000, p. 15-23. A adjetivação éddico, referente às Eddas, nós conservamos da forma usual utilizada pelos escandinavistas franceses, ingleses, escandinavos e italianos, conservando o duplo d.

5 A Völuspá é uma fonte central nos estudos sobre mitologia escandinava, sendo o poema nórdico medieval mais famoso. Para um panorama introdutório na estrutura, bibliografia e história sobre os estudos da Völuspá, consultar: LINDOW, John - Mythology and mythography in LINDOW, John \& CLOVER, Carol (orgs.) - Old Norse icelandic literature: a critical guide. Toronto: University of Toronto, 2005, p. 29-32, 40-41, 48, 52-53. O melhor panorama dos estudos sobre a Völuspá, do século XIX até a década de 1950 é disponível em: NORDAL, Sigurður - Three essays on Völuspá. Saga-book 3 (18), 1972, p. 79-91.
} 
Völuspá é geralmente datada por volta do ano 1000 , de autoria islandesa ${ }^{6}$ e obedece a seguinte estrutura básica: o passado (estrofes 3-27), o presente mítico (30-43), o futuro até o Ragnarök (44-58), o futuro após o Ragnarök (59-65). ${ }^{7}$ O Vafprúđnismál (A canção de Vafprúðnr) é o terceiro poema éddico inserido no manuscrito GKS 2365 4to, (c. 1270), possuindo também uma versão parcial no AM 748 I 4to, datado de início do século XIV. ${ }^{8}$ Sua estrutura básica refere-se a diálogos entre os deuses Odin e sua esposa Frigg e o gigante Vafprúðnr, comentando sobre acontecimentos do universo, dividindo os poemas entre o passado (vv. 20-35), o presente (36-43) e o Ragnarök (44-54). A data de composição do poema é creditada como sendo a mesma do Völuspá, em meados do século $\mathrm{X} .^{9}$

Em um ponto de vista historiográfico, podemos separar as concepções sobre o Ragnarök na academia em três idéias principais: os que acreditavam que as narrativas sobre o destino dos deuses germânicos seriam de base totalmente pagã; os autores que perceberam interferências cristãs sobre uma composição pagã e a recontaram após o registro escrito; e mais recentemente, os que defendem que o compositor original foi um pagão que sofreu influências de idéias cristãs durante o período de conversão.

Desde o século 19, com a publicação das principais fontes da história e literatura escandinava, os antigos mitos foram valorizados dentro de uma perspectiva nacionalista e folclórica, não recebendo os manuscritos que foram preservados nenhum tipo de crítica interna ou que ligasse ao momento histórico e social de sua composição. Deste modo, os primeiros estudos sobre o Ragnarök não realizaram questionamentos sobre interferências literárias ou de outras religiosidades em uma suposta narrativa de origem pagã. O sueco Rudolph Keyser, em seu livro Normændenes Religions Forfatning í

\footnotetext{
${ }^{6}$ NORTH, Richard - Völuspá and the Book of Revelation in SIMEK, Rudolf \& MEURER, Judith. Scandinavian and Christian Europe in the Middle Ages: Papers of the $12^{\text {th }}$ International Saga Conference, Bonn, 2003, p. 1.

${ }^{7}$ MCKINELL, John - Both one and on many: essays on change and variety in late norse heathenism. Roma: Il Calamo, 1994, p. 105-112.

${ }^{8}$ LINDOW, John - Vafthrúdnismál. Norse mythology. Oxford: Oxford University Press, 2001, p. 304307.

${ }^{9}$ BELLOWS, Henry Adams - Introductory note. The poetic Edda. New York: Dover, 2004, p. 68; MCKINELL, Op.ci.t, p. 105. Para elementos analíticos e estruturais deste poema, consultar: HARRIS, Joseph - Eddic poetry in LINDOW, John \& CLOVER, Carol (orgs.). Old Norse icelandic literature: a critical guide. Toronto: University of Toronto, 2005, p. 75-76, 85, 93, 98.
} 
Hedendommen, ${ }^{10}$ descreveu o relato do fim dos deuses de forma muito próxima as das fontes, de forma descritiva e sem qualquer reflexão histórica sobre o contexto de preservação desta tradição. Essa tendência seguiria as publicações da primeira metade do século seguinte, que influenciados pelos estudos de mitologia comparada, procuravam ver nas narrativas de destruição do mundo pelos persas, gregos, celtas e outros povos, um suposto indício da autenticidade da tradição nórdica, tendo um fundo em comum especialmente entre os povos europeus mais antigos. Assim, o livro The Celtic and scandinavian religions, de 1948, apesar de evidenciar certas influências cristãs na Edda de Snorri, acreditava que o poeta anônimo da Völuspá era totalmente pagão. $^{11}$

Mas um dos teóricos que mais propagou a imagem das fontes nórdicas como pertencentes a um passado europeu em comum foi Georges Dumézil. Para ele, a batalha escatológica entre os deuses e monstros, os cataclismos e a volta de Balder são imagens presentes no mundo iraniano, persa, zoroastriano - baseando-se numa comparação entre as Eddas e o Mahabharata dos hindus. Com isso, os germanos possuiriam imagens míticas pertencentes ao patrimônio cultural de todos os indo-europeus, não sofrendo variação em sua estrutura básica ${ }^{12}$ - a denominada tripartição, altamente contestada pela historiografia contemporânea. Dumézil não incluiu em seus estudos uma avaliação contextual das fontes, nem possíveis variações de conteúdo do período oral ao momento em que foram preservadas por escrito, nem mesmo influências sociais do momento histórico em que a poesia éddica foi preservada literariamente. ${ }^{13}$

A partir dos anos 1920, os estudos sobre o Ragnarök começaram a incluir a possibilidades das fontes escritas terem sido influenciadas pelo referencial cristão (interpretatio christiana), numa trilha iniciada anteriormente por Axel Olrik ${ }^{14}$ - mas

\footnotetext{
${ }^{10}$ KEYSSER, Rudolph - The religion of the northmen. New York: Astor Library, 1854, p. 101-102.

${ }^{11}$ MACCULLOCH, J. A. - The Celtic and scandinavian religions. New York: Hutchinson University Library, 1948, p. 166.

12 DUMÉZIL, Georges - Mythologie indo-européenne et mythologie germanique. Mythes et dieux des germains: essai d'interpretation comparative. Paris: Librairie Ernest Leroux, 1939, pp. 3-16; DUMÉZIL, Georges - Ragnarök. Loki (1948). Paris: Flamarion, 1986, pp. 248-256.

${ }^{13}$ Para uma síntese das reavaliações da obra de Dumézil, consultar: ORTON, Peter - Pagan myth and religion in MCTURK, Rory (ed) - A company to Old Norse-Icelandic Literature and culture. London: Blackwell Publishing, 2007, p. 313-314.

${ }^{14} \mathrm{O}$ folclorista dinamarquês Axel Olrik publicou seu estudo em duas partes: Aarb nord Oldkynd, em 1902, e Dan Stud em 1913, e de forma completa em 1922, mas em alemão: Ragnarök, die Sagen vom
} 
que somente neste momento começa a ter maior respaldo acadêmico. Em sua edição da Völuspá de 1923, o professor Sigurdr Nordal realizou alguns ensaios críticos que se tornaram muito influentes. Ele reconhecia no poema éddico diversos elementos advindos da Bíblia, especialmente o Apocalipse, mas ao contrário de Olrik, acreditava que estes não poderiam ser facilmente compreendidos, apontando caminhos para análises estruturais e comparativas. ${ }^{15}$

Outros mitólogos continuaram a perspectiva criada por Olrik e Nordal. Em seu livro mais famoso, Hilda Davidson admitia os efeitos da visão de fim do mundo bíblico sobre o imaginário nórdico durante o século X e XI e na composição da Völuspá, mas insiste em um fundo originalmente pagão. Para isso, recorre a alguns pontos essenciais: A - a semelhança entre as narrativas escatológicas celtas e germânicas; B - referências ao fim do mundo em inscrições rúnicas e poemas escáldicos do século XI; C - imagens do Ragnarök em esculturas britânicas alto-medievais; D - sobrevivência de narrativas escatológicas nórdicas no folclore. ${ }^{16}$ Posteriormente, a autora admite maiores influências cristãs também na arte anglo-escandinava e nas narrativas escritas e rúnicas, mas ainda insiste na continuidade de uma tradição arcaica dos indo-europeus: após um terrível inverno, ocorrerá a deterioração da vida na terra e o abandono da lei e da realeza. $^{17}$

Outro mitólogo muito influente, o francês Régis Boyer, segue na mesma perspectiva de Hilda Davidson, inclusive com as mesmas influências teóricas de Dumézil e Mircea Eliade. Para Boyer, o poeta da Völuspá fundiu ao referencial pagão, diversas crenças mitológicas ocidentais e orientais, incluindo as idéias maniqueístas persas, a idade de ouro clássica e os motivos apocalípticos bíblicos. ${ }^{18}$

Weltuntergang. Conf.: DAVIDSON, Hilda - Myths and symbols in Pagan Europe: early Scandinavian and celtic religions. London: Syracuse Press, 1988, p. 244.

${ }^{15}$ NORDAL, Sigurðr - Three essays on Völuspá. Saga-book 3 (18), 1972, p. 79-135.

${ }^{16}$ DAVIDSON, Hilda - Deuses e mitos do Norte da Europa (1964). São Paulo: Madras, 2004, pp. 161178.

17 DAVIDSON, Hilda - Myths and symbols in Pagan Europe: early Scandinavian and celtic religions. London: Syracuse Press, 1988, p. 188-195. Em trabalhos mais recentes, a pesquisadora ainda insiste na comparação do fim do mundo nórdico com as narrativas persas, que relatam a sobrevivência de um grande inverno. DAVIDSON, Hilda - Escandinávia. Lisboa: Editorial Verbo, 1987, p. 121.

${ }_{18}$ BOYER, Régis - Yggdrasill: La religion des anciens scandinaves. Paris: Payot, 1981, pp. 201-106; BOYER, Régis - Ragnarök. Héros et dieux du Nord: guide iconographique. Paris: Flammarion, 1997, pp. 125-126. 
Além das análises mitológicas, também estudiosos da conexão entre literatura, história e sociedade conseguiram perceber os manuscritos em outras perspectivas. A Völuspá, por exemplo, não teria sido apenas uma mera adaptação racionalista dos mitos pagãos para o imaginário cristão, mas um reflexo objetivo da política dos séculos XII e XIII na Islândia e Noruega, sendo uma narrativa que previa o surgimento de um novo governante para novamente conceder ordem no mundo. ${ }^{19}$

Algumas das perspectivas mais recentes propõem a idéia de uma interpretatio norrona - os poetas pagãos reinterpretaram imagens cristãs, transformando seus cultos e mitos originais. ${ }^{20}$ Desta forma, a mitologia do Ragnarök teria se formado no momento de uma tradição oral e pagã (ainda que em sua forma final e derradeira), não sendo uma adição posterior à narrativa definitiva por parte dos escritores cristãos (que deram forma definitiva aos poemas éddicos em seu formato manuscrito). Mesmo assim, a idéia da recriação do mundo seria genuinamente pré-cristã. ${ }^{21}$ Neste sentido, os estudos mais exaustivos foram publicados pelo britânico John Mckinnell. Em 1992, o pesquisador comparou as imagens do Ragnarök presentes nos poemas éddicos Vafprúðnismál e Völuspá, concluindo que o primeiro mantém uma tradição pagã original e seus valores guerreiros e éticos intrínsecos, enquanto o segundo também é um poema pagão, mas eticamente influenciado pelo cristianismo e seus critérios morais - ambos coexistindo na mesma região e época. ${ }^{22}$ Posteriormente, Mckinnell reforça sua perspectiva que a Völuspá refletia idéias da nova religião, mas que seu compositor não era cristão - ele manteve uma estreita circularidade entre rituais, possuía experiência catecumênica, conhecia os escritos latinos e germânicos (especialmente o poema Muspilli, c. 870). A

${ }^{19}$ WÜRTH, Stefanie - Ragnarök: Götterdämmerung und Weltende in der nordischen Literatur in ROSS, Margaret Clunies \& BARNES, Geraldine. Old Norse Myths, literature and society. Sydney: University of Sydney, 2000, pp. 580-589.

${ }^{20}$ Para outros pesquisadores, porém, a idéia da morte dos principais deuses seria inconcebível para guerreiros pagãos que sempre os tinham como vitoriosos, sendo o Ragnarök produto de idéias religiosas no período de transição do paganismo ao cristianismo, não fazendo parte da mitologia original. CHRISTIANSEN, Eric. Op.cit., p. 299.

${ }^{21}$ SØRENSEN, Preben Meulengracht - Religions Old and New in SAWYER, Peter (org.). The Oxford Ilustrated History of the Vikings. Oxford: Oxford University Press, 1997, p. 213.

${ }^{22}$ Mckinnell, Op.cit. p. 107-128. 
situação original e arcaica - encontro entre a profetisa e Odin - foi preservada, sendo somente 20 das 66 estrofes com influência diretamente cristã. ${ }^{23}$

\section{As fontes iconográficas}

A mitologia escandinava possui muitas representações visuais, especialmente as produzidas na área sueca durante os séculos VIII e IX. Mas não existem imagens originalmente pagãs produzidas na Era Viking sobre o Ragnarök. Em nossos estudos anteriores sobre imagética da ilha báltica de Gotland - a mais rica área com fontes iconográficas míticas - percebemos que a grande maioria das representações diz respeito ao deus Odin - a chegada ao Valhalla, a recepção das valquírias, o sucesso nas batalhas, a morte honrosa na guerra. ${ }^{24}$ Outras narrativas míticas ocupam um espaço menor, mas significativo na área sueca, como as representações de Gunnar e a pesca da serpente do mundo por Thor. Porém, em nenhum momento ocorreram representações visuais do fim do mundo nórdico. Isso nos leva a duas perspectivas neste momento: ou realmente o Ragnarök não fazia parte da cosmologia escandinava pré-cristã - mais especificamente, a morte dos principais deuses -, ou ocupava um espaço não muito importante, sem grande relevância para a religiosidade e para a expressão icônica e social, sobrevivendo apenas em algumas narrativas orais que foram depois definitivamente compostas, reelaboradas e preservadas já em um contexto cristão.

\footnotetext{
23 MCKINELL, John - Völuspá and the feast of Easter. Alvíssmál 12, 2008, pp. 3-28. Também destacamos as pesquisas de Ursula Dronke, que observou influências dos poemas Cantus Sibyllae e Prophetiae Sybyllae magae, realizados na Inglaterra entre os séculos IX e X, e Richard North, que reafirmou influências do Livro das Revelações, mas também a base pagã do poeta, onde a renovação do mundo seria uma imagem arcaica da Escandinávia. Conf. NORTH, Richard. Op. cit., p. 1-11.

${ }^{24}$ LANGER, Johnni - O culto a Odin entre os vikings: uma análise iconográfica da estela de Hammar I. Deuses, monstros, heróis: ensaios de mitologia e religião viking. Brasília: Editora da UNB, 2009, pp. 79108; LANGER, Johnni - As estelas de Gotland e as fontes iconográficas da mitologia viking. Brathair 6, 2006, pp. 10-41.
} 


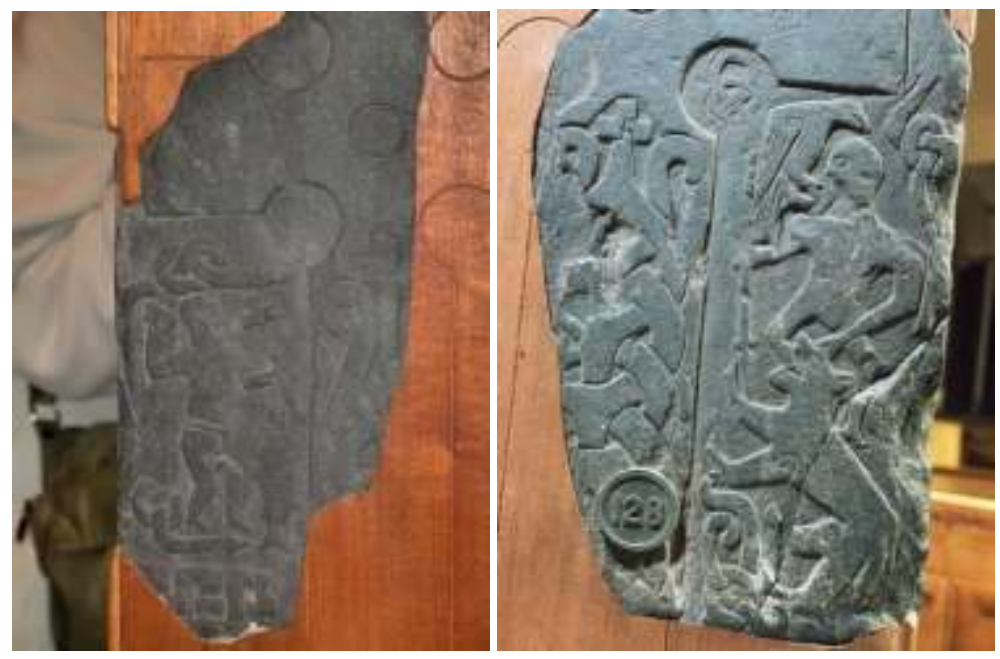

Figura 1: As duas faces da cruz de Thorwald (Andreas 128), Ilha de Man, 900-950 d.C.. Fonte: GLOT, Claudine \& LE BRIS, Michel (orgs.). L’Europe des Vikings. Paris: Hoebeke, 2004, p. 92. A primeira face pode ser a representação de um missionário cristão, vencendo Satã (a serpente com nó) pela cruz e com a Bíblia. Na outra face, vemos a representação de Odin com corvo e sua lança mágica, Gungnir, sendo devorado pelo lobo Fenrir. A serpente ao lado pode ser uma alusão à Jörmungandr, a serpente do mundo na tradição nórdica. No seu lado esquerdo, uma suástica (símbolo odínico) se funde a uma pequena cruz cristã.

As duas representações visuais mais antigas e importantes do Ragnarök surgem em monumentos cristãos das ilhas britânicas: a cruz de Thorwald na Ilha de Man (Andreas 128) e outra na Inglaterra (Gosforth 1, Cumbria), ambas datadas na primeira metade do século X. A maior parte dos estudos analisou suas imagens apenas relevando seu conteúdo temático. Neste momento, faremos três níveis de interpretação: primeiro, analisando estes monumentos dentro do contexto da ocupação escandinava no mundo britânico; em segundo, comparando suas imagens (temas, estilo, contexto espacial) com a cultura visual e mitológica da área escandinava; e em terceiro, o conteúdo temático dentro do contexto da cristianização dos nórdicos, a composição da Völuspá e as diferentes fontes literárias sobre o Ragnarök. 


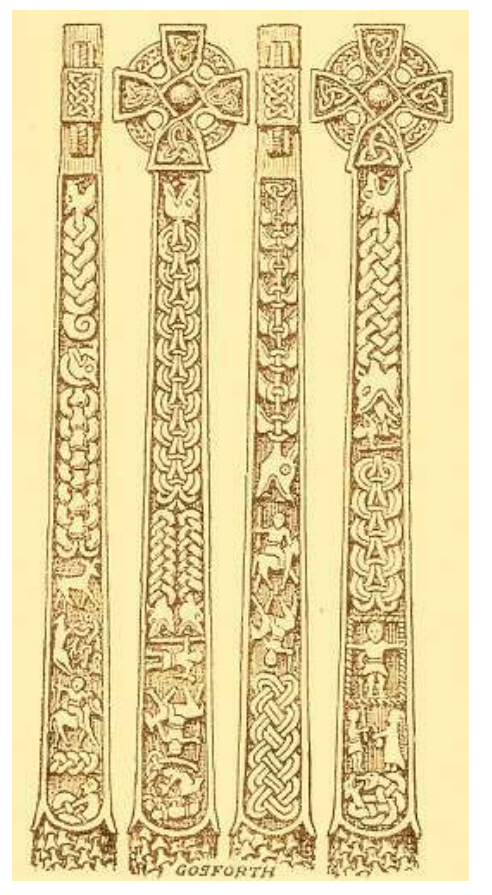

Figura 2: A cruz de Gosforth 1, Cumbria, Inglaterra, 920-950 d.C. Respectivamente, do lado esquerdo para o direito, face Sul, face Oeste, face Norte e face Leste. Fonte: LANGER, Johnni. O mito do dragão na Escandinávia (parte dois: as Eddas e o sistema ragnarokiano). Brathair 7(1), 2007, p. 77.
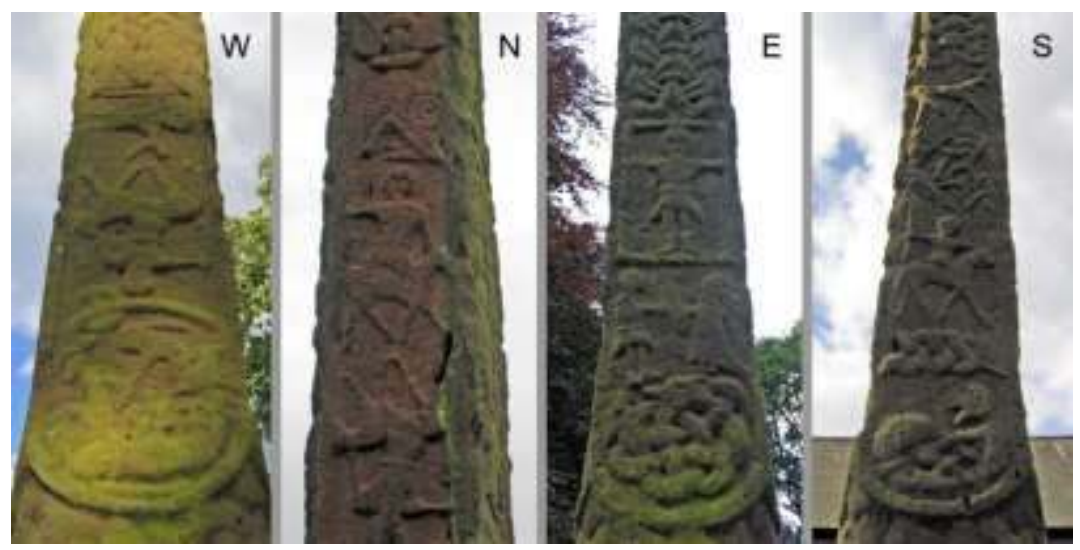

Figura 3: Detalhes da cruz de Gosforth 1, Cumbria, Inglaterra, 920-950 d.C., respectivamente, face Oeste, face Norte, face Leste e face Sul. Fonte: GRANT, John. Introdução à mitologia Viking. Lisboa: Editorial Estampa, 2000, p. 116 e 118. 
A cruz de Thorwald (Andreas 128, ver figura 1) é um bloco de rocha fragmentado contendo gravuras em alto relevo em ambas as faces. Na face mais preservada, na base da cruz de formato celta-irlandês, ocorre um entrelaçamento de duas linhas de formato serpentiforme, cujo cimo se transforma em uma suástica ao centro. Também ocorrem mais três representações de suásticas e três símbolos entrelaçados mais acima, entre os quais uma serpente. Ao lado da cruz, ocorre a famosa representação do deus Odin, em cujo ombro direito se assenta a figura de um pássaro (possivelmente, um de seus corvos). A figura de um lobo, Fenrir, abocanha a sua perna direita. A lança de Odin se posiciona para baixo, tocando a base da perna do lobo - alguns pesquisadores perceberam isso como um sinal da derrota eminente da divindade, ${ }^{25}$ o que pode ser confirmado pela presença da mesma situação em figuras da cruz de Gosforth (cavaleiros com a ponta da lança para baixo). Do outro lado do monumento, ocorre a representação de uma figura masculina segurando um objeto quadrado com a mão direita (possivelmente uma Bíblia) e com a outra uma cruz. Ele pisa em uma serpente entrelaçada, enquanto em sua frente ocorre a imagem de um peixe. Alguns analistas quiseram ver nesta figura a representação de Cristo, mas acreditamos que se trata de algum missionário ou evangelizador, derrotando o demônio pela palavra de Deus.

Qual o sentido da cruz de Thorwald? Simplesmente a representação da derrota do deus nórdico mais importante e a vitória de Cristo em um monumento claramente propagandístico? Em primeiro lugar, temos que analisar este objeto junto ao contexto artístico da Ilha de Man. Os vikings chegaram a esta região durante o final do século IX, vindos da Noruega via Escócia e Irlanda e rapidamente foram cristianizados. Não há neste local nenhum tipo de representação pictórica, escultural e simbólica que ateste monumentos religiosos totalmente pagãos. Mas isso não quer dizer que a tradição artística escandinava não tenha sobrevivido. Muitos dos nórdicos instalados na ilha tornaram-se latifundiários que encomendaram a fabricação de cruzeiros em pedra, ${ }^{26} \mathrm{e}$ algumas inscrições atestam como escultores das obras também escandinavos, como

\footnotetext{
${ }^{25}$ DAVIDSON, Hilda - Escandinávia. Lisboa: Editorial Verbo, 1987, p. 122.

${ }^{26}$ A existência de sepulturas conservando a práticas de inumação com objetos cotidianos e de guerreiros indica que os primeiros colonizadores ainda eram pagãos. Conf. CAMPBELL, James-Graham. Os viquingues. Madrid: Del Prado, 1997, p. 157.
} 
Gaut Björnsson (c. 950). ${ }^{27}$ As cruzes possuem influências estéticas provenientes da Irlanda e da Inglaterra, sendo que a maioria dos motivos esculpidos são temas da mitologia nórdica. Algumas destas cenas já haviam sido retratadas na área escandinava, como representações de valquírias e Gunnar no fosso das serpentes (ver tabela 1), mas outras são exclusivas das ilhas britânicas, a exemplo de Loki junto a Otr e Heimdall tocando seu corno (ver tabela 2).

Comparando a cruz de Thorwald com as cenas dos outros monumentos das ilha britânicas, podemos ter algumas constatações. Primeiro, a imagem de que Odin como deus supremo e inspirador da guerra ainda reinava soberana no imaginário dos escandinavos do local, recentemente cristanizados. Em um fragmento de Jurby 125 (Man), em um dos lados da base da cruz, vemos a escultura de uma valquíria, e logo abaixo, um homem carrega um enforcado por um bastão entre os ombros. Do outro lado da base da cruz, ocorre a figura de um alce ou cervo. Mesmo que não se trate objetivamente da figura do deus caolho, como queria Kermode, ${ }^{28}$ a cena está ligada aos cultos odínicos - o ato de morrer (seja por sacrifício ou por morte em batalha), seguido da recepção pelas donzelas no Valhala. O quadrúpede galhado é símbolo do êxtase xamânico, inerente aos ritos desta deidade, presente também em moedas da Era Viking. Ou seja: o conjunto cênico concede ao paganismo um sentido eminentemente positivo. As deidades não são representadas de forma pejorativa ou depreciativa: em outras cruzes da área britânica, como Yorkshire, o deus Odin foi representado com elmo e dois corvos pousados em seu ombro, ${ }^{29}$ da mesma forma que em contextos tipicamente précristãos da Escandinávia. Temos que ter em conta que a maioria destes monumentos, apesar de terem sido preservados em sítios eclesiásticos, originalmente foram concebidos como monumentos funerários - ou seja, eles possuíam a finalidade de reforçar os principais elementos vinculados à cultura e a ideologia guerreira pré-cristã ${ }^{30}$

\footnotetext{
${ }^{27}$ HAYWOOD, John - Manx crosses. Encyclopaedia of the Viking Age. London: Thames and Hudson, 2000, p. 128. Para maiores detalhamentos históricos, artísticos, estilísticos e de datações dos monumentos da Ilha de Man, consultar: WILSON, David - Manx memorial Stones of the Viking Period. Saga-Book 18, 1970-1971, p. 1-18.

${ }^{28}$ KERMODE, P.M.C. - Traces of the norse mythology in the Isle of Man. London: Bemrose \& Sons, 1904 , p. 19.

${ }^{29}$ LANG, J. T - Anglo-scandinavian sculpture in Yorkshire in HALL, Richard (ed.) - Viking Age and the North. London: Council for British Archaeology, 1978, p. 12.

30 "Courage, strength and loyalty towards kin were the Vikings's strong ideals". SPRAGUE, Martina Norse warfare: the unconventional battle strategies of the ancient Viking. New York: Hippocrene Books, 2007 , p. 46. Em específico para a tradição iconográfica escandinava, temos: "strength, prowess, power,
} 
a força (simbolizada pelos equipamentos para batalha, cujo exemplo mais famoso é a base da cruz de Middleton, onde ao lado de um guerreiro, foram retratados um escudo, lança, espada, machado e uma adaga), ${ }^{31}$ a coragem (o enfrentamento das bestas, como as várias cenas do ciclo de Sigurd, especialmente a morte de Fáfnir por este herói: cruzes de Jurby 119 e Malew 120), e a lealdade/honra (Gunnar no fosso das serpentes, cruz de Andreas 121). Estes elementos constituíam a essência do comportamento aristocrático e do guerreiro nórdico, não desaparecendo após a mudança religiosa, motivo pelo qual eles sobrevivem por meio das representações míticas na arte de objetos cristãos.

Acreditamos que os monumentos da Ilha de Man e grande parte das cruzes inglesas atestam a cristianização dos escandinavos, mas não sua total conversão: eles ainda conservaram o ideário religioso e ético do paganismo, convergindo numa dinâmica transformação e adaptação de valores. ${ }^{32}$ Conforme conheciam cada vez mais a nova religiosidade, procurava-se adaptar os antigos mitos à cultura bíblica e missionária. Assim, percebemos a causa de antigas representações tradicionais não serem mais incorporadas nesta realidade - por exemplo, não ocorrem na área britânica imagens de navios - símbolos de status e prestígio, além de representação da passagem da vida para a morte. ${ }^{33} \mathrm{E}$ ao contrário da iconografia na área nórdica, a arte britânica tendia a selecionar cenas relacionadas com o fim do mundo.

Talvez o exemplo mais refinado desta tendência seja a cruz de Gosforth 1 na região da Cumbria, Inglaterra (ver figuras 2 e 3). Trata-se de um complexo monumento com

courage, and other manly virtues". FUGLESANG, Signe Horne - Iconographic traditions and models in Scandinavian imagery in BARNES, Geraldine \& ROSS, Margaret Clunie (orgs.) - Old Norse myths, literature and society. Proceedings of the $11^{\text {th }}$ International Saga Conference. Sidney: University of Sidney, 2000, p. 9.

${ }^{31}$ HALL, Richard - Viking Age Archaeology in Britain and Ireland. London: Shire Publications, 2010, p. 12. Para o arqueólogo Richard Bailey, as representações de guerreiros armadas na arte britânica do século $\mathrm{X}$ correspondem aos aristocráticos ideais militares da nova liderança política e econômica da Northumbria. Cf. BAILEY, Richard - Scandinavian myth on viking-period Stone sculpture in England in BARNES, Geraldine \& ROSS, Margaret Clunie (orgs.) - Old Norse myths, literature and society. Proceedings of the $11^{\text {th }}$ International Saga Conference. Sidney: University of Sidney, 2000, p. 16.

${ }^{32}$ A maior parte dos estudos sobre a relação entre religiosidade germânica e cristã teve uma posição do processo de cristianização como força ativa e do paganismo germânico como passivo ou reacionário. RUSSELL, James - The germanization of early medieval Christianity: a sociohistorical approach to religious transformation. Oxford: Oxford University Press, 1994, p. 38.

${ }^{33}$ LANGER, Johnni - As estelas de Gotland e as fontes iconográficas da mitologia viking. Brathair 6, 2006, p. 16. 
gravuras nas quatro laterais, decorado no estilo Bore da tradição nórdica. ${ }^{34}$ As imagens seguem uma narrativa seqüencial, com cenas de grande drama cósmico unindo o mundo nórdico e cristão, mas destacando símbolos e mitos relacionados com o derradeiro momento dos deuses e homens.

O motivo dominante de Gosforth é a cabeça de um lobo, cujo corpo entrelaça-se, terminando em outra cabeça canídea, ou com estrutura corpórea transformando-se em pequenas asas. Uma das cabeças foi esculpida defrontando a boca aberta contra um cavaleiro armado de lança, possivelmente o deus Odin (Face norte); em outro lado da cruz, duas cabeças de monstros são seguras por uma lança de um guerreiro, que em outra mão porta um corno (Face Oeste). Alguns pesquisadores acreditam que se trata do deus Heimdall. No mesmo conjunto, um cavaleiro é representado de ponta cabeça uma alusão à queda de Odin? ${ }^{35}$ Logo abaixo, em um nicho formado por linhas entrelaçadas, uma figura feminina segura um corno defronte a outra figura, presa no pescoço e nas mãos. Com certeza, uma representação do castigo de Loki e da companhia de sua mulher, Sygni. A face frontal mais famosa da cruz apresenta duas cena separadas (Face Leste). A primeira, onde uma cabeça lupiniana é segura por um guerreiro portando lança, cuja mão abre a mandíbula superior e a perna adentra a língua bifurcada e estende a mandíbula inferior - uma alusão a Vithar matando Fenrir durante a batalha de Vígríd. A segunda cena, na base, mostra a crucificação de Cristo.

Alguns pesquisadores acreditam que a cruz de Gosforth não seja um produto sincrético entre as duas religiosidades, mas um monumento com clara conotação e mensagem cristã. ${ }^{36}$ Dentro de nossa linha interpretativa, percebemos este em um contexto

\footnotetext{
${ }^{34}$ HOLMAN, Catherine - Gosforth cross. Historical dictionary of the Vikings. Oxford: The Scarecrow Press, 2003, p. 107. Para outros detalhes básicos sobre esse monumento, verificar: PULSIANO, Philip \& WOLF, Kirsten (Eds.) - Medieval Scandinavia: an encyclopedia. London: Routledge, 1993, p. 697; BAILEY, Richard - Gosforth cross in LAPIDGE, Michael (org.). The Blacwell Encyclopaedia of AngloSaxon England. London: Blacwell, 2001, 213-214.

${ }^{35}$ Alguns pesquisadores percebem essa figura como a representação de Heimdall combatendo e sendo morto durante o Ragnarok por Loki, que se situa em uma cena logo abaixo. BAILEY, Richard Scandinavian myth on viking-period Stone sculpture in England in BARNES, Geraldine \& ROSS, Margaret Clunie (orgs.) - Old Norse myths, literature and society. Proceedings of the $11^{\text {th }}$ International Saga Conference. Sidney: University of Sidney, 2000, p. 21.

36 "But in neither case we dealing with syncretism, though the mind is drawn to parallels and contrasts between Christian teaching and Scandinavian-based mythology; the message is Christian". BAILEY, Richard - Scandinavian myth on viking-period Stone sculpture in England in BARNES, Geraldine \& ROSS, Margaret Clunie (orgs.) - Old Norse myths, literature and society. Proceedings of the $11^{\text {th }}$ International Saga Conference. Sidney: University of Sidney, 2000, p. 22. Já para o arqueólogo Richard
} 
diferente: na realidade trata-se de uma obra artística que revela o enorme hibridismo cultural que vivia a sociedade neste momento, atestando a adaptação de valores pagãos ao cristianismo. Dois aspectos da cruz são primordiais para este ponto de vista e foram totalmente negligenciados pelos analistas. Primeiramente, na cena de crucificação - que ocupa um nicho retangular formado por linhas trançadas - vemos Cristo sendo perfurado pela lança de Longinus, que se encontra abaixo deste nicho. ${ }^{37} \mathrm{Em}$ frente ao guerreiro romano, uma mulher oferece um corno de bebida. Quando a cena é vislumbrada apenas olhando para Longinus e Cristo (de cima para baixo ou ao contrário), percebemos uma imagem cristã. Mas quando o observador se concentra apenas na cena inferior (da esquerda para a direita ou vice versa), vai olhar para uma típica representação presente na área pagã escandinava - uma valquíria recebendo o herói morto no Valhalla. ${ }^{38}$ Para o referencial de um ex-politeísta, os diferentes mundos podem se ligar de alguma forma, sendo uma inteligente justaposição de imagens capaz de levar o sentimento ambíguo presente no patrocinador do monumento.

Hall, a inclusão de temas nórdicos em monumentos cristãos reflete um "gosto eclético" por parte dos patrocinadores e artistas. HALL, Richard - Exploring the world of the Vikings. London: Thames and Hudson, 2007, p. 113. Alguns concebem um hibridismo cultural nas duas tradições: "Viking Age sculpture in northern England is sometimes found on earlier christian sites, it shows points of continuity with Anglian traditions, and duly, as at Gosforth, assimilated the Christian message; but it did note ignore the pagan Scandinavian past”. WORMALD, P. - Scandinavian Settlement in CAMPBELL, James (Ed.) The Anglo-Saxons. London: Penguin Books, 1982, p. 162-163. Mas a visão que mais se aproxima de nosso referencial é a de Lilla Kopár: "The carvings with mixed iconography were the result of the mingling of traditions, where everyone contributed something from his or her cultural heritage. It was not the incompatibility of two religious systems, but the compatibility of different cultural traditions which the sculptors of these monuments perceived and represented. The iconographical material of different origins was considered to be of equal importance, and the pagan figural elements were featured on the prominent sides of the monuments, together with the Christian ones. Thus it is highly improbable that the purpose of these carvings would have been to promote the superiority of Christian over the pagan gods". KOPÁR, Lilla - An intercultural dialogue set in Stone. VIN Seminar I: Myth and cultural memory in the Viking Diaspora. Leicester, UK, 2007, p. 11.

${ }^{37} \mathrm{Na}$ arte britânica alto medieval, ocorreram outras representações de Longinus, como as cenas presentes nas cruzes da ilha Calf of Man e Llangan, no País de Gales (SEABORNE, Malcolm - Celtic crosses of Britain and Ireland. Oxford: Shire Publications, 1994, p. 28 e 33). Mas nestas duas cenas, Longinus se situa ao lado do Cristo crucificado e não abaixo deste.

${ }^{38}$ A imagem feminina na face Leste é totalmente idêntica as valquírias representadas em pingentes e amuletos da Era Viking. E o conjunto da cena, o guerreiro frente à mulher com corno, é especialmente semelhante às cenas de valquírias recebendo o herói no Valhalla presente em Ardre VIII, Hammar I, Tjangvide, entre outros monumentos escandinavos pré-cristãos. 

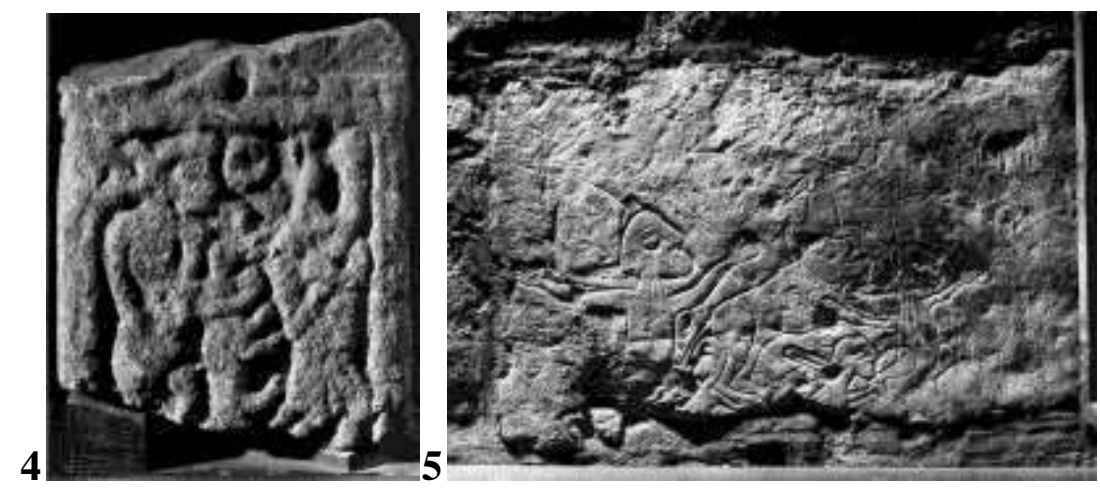

Figura 4: Hogback de Ovingham 1C, Northumberland, Inglaterra, 900-950 d.C. Fonte: Corpus of Anglo-Saxon Stone Sculpture: http://www.dur.ac.uk/sculpturecorpus/ Ao lado de uma mulher, uma figura masculina segura um corno de grandes dimensões (Heimdall). Entre eles, uma figura canídea com a boca aberta avança sobre um círculo (Hati ou Skol).

Figura 5: Grafite de Skipwith 1, Eastern Yorkshire, Inglaterra, 900-950 d.C. Fonte: Corpus of Anglo-Saxon Stone Sculpture: http://www.dur.ac.uk/sculpturecorpus/ Num conjunto de várias figuras masculinas com os braços abertos (tipicamente nórdicas, pelo tipo de elmo e presença de barba), um animal de formas canídeas (Fenrir?) ataca a perna de um homem (Odin?). O sentido do conjunto é de confusão e desespero, algo bem próximo da idéia escandinava de Ragnarök. Mas estão ausentes algumas das típicas representações odínicas: lanças, pássaros, suásticas, cavalos.

Outros elementos reforçam nosso ponto de vista. Os braços no cimo do cruzeiro de Gosforth (face Oeste e face Leste) são ornamentados com triquetras, símbolos de Odin presentes na área escandinava de Gotland ${ }^{39}$ - mas também no mundo angloescandinavo, ocorrendo em hogbacks - pedras tumulares construídas na área escocesa e inglesa, que contém símbolos e imagens do paganismo nórdico especialmente na região da Cumbria, datados do início do século X. O hogback de Brompton apresenta além de triquetras, ursos ladeando o monumento - animais também relacionados aos cultos

\footnotetext{
${ }^{39}$ Talvez a mais representativa alusão da triquetra enquanto símbolo odínico seja a estela de Sanda 2, em Gotland, onde foi esculpida ao lado do trono do deus caolho. Conforme: LANGER, Johnni - Símbolos religiosos dos vikings: guia iconográfico. História, imagem e narrativas 11, 2010, p. 12.
} 
odínicos, especialmente a elite guerreira conhecida como berserkir. ${ }^{40}$ Dentro do imaginário escandinavo, o urso simboliza a força, enquanto que a representação de alguns mitos reforçou outros aspectos da ideologia guerreira: o deus Týr colocando sua mão na boca do lobo Fenrir (a lealdade/honra, hogback de Sockburn); a figuração de um homem lutando conta serpentes (a coragem, hogback da Igreja de St. Mary).

Ao contrário de outros acadêmicos, pensamos que o monumento de Gosforth possui uma sequência de leitura e ordem cronológica. ${ }^{41}$ A narrativa se inicia na Face Sul, onde percebemos dois animais, um cervídeo, e mais abaixo, um canídeo entrelaçado a várias linhas. Depois, surge a figura de um cavaleiro, e próximo à base, uma figura humanóide sendo atacada por uma besta, que alguns interpretaram como sendo o deus Týr. ${ }^{42}$ Esta lateral da cruz deve aludir a fuga dos monstros Fenrir e Garm, relacionados ao início do Ragnarök. A sequência é o lado Oeste da cruz, onde Heimdall anuncia pelo toque de seu corno a eminente queda da ordem, ao mesmo tempo em que Loki está preso, mas deve se libertar brevemente. Imediatamente, o lado Norte representa a morte de Odin, enquanto que a face Leste é a final, mostrando o combate de Vithar com Fenrir, a morte

\footnotetext{
${ }^{40}$ Os hogbacks comemoram o culto guerreiro, destacando a moradia cósmica que Odin escolheu para seus eleitos (eles possuem a forma de casas, talvez sejam também símbolos do Valhalla). Conf. STONE, Alby - Hogbacks: Christian and pagan imagery on Viking Age monuments. $3^{\text {rd }}$ Stone 33, January-march 1999, pp. 16-20. Os hogbacks não possuem equivalentes na área dinamarquesa, sendo influenciados esteticamente pela arte anglo-saxã, especialmente relicários e confeccionados no estilo Jelling. Não há certeza se realmente cobriam áreas tumulares. HAYWOOD, John - Hogbacks. Encyclopaedia of the Viking Age. London: Thames and Hudson, 2000, p. 97-98. Alguns pesquisadores acreditam que a figura dos ursos nestes monumentos sejam símbolos da conversão dos escandinavos para o cristianismo, KOPÁR, Lilla - An intercultural dialogue set in Stone. VIN Seminar I: Myth and cultural memory in the Viking Diaspora. Leicester, UK, 2007, p. 9. Mas a tradição religiosa dos antigos povos germânicos, celtas, eslavos, escandinavos e finlandeses relacionando os ursos a cultos xamânicos e guerreiros era muito antiga (conf. TOOLEY, Clive - Hrólfs Saga Kraka and Sámi bear rites. Saga-Book 31, 2007, pp. 521). A presença de ursos e triquetras num mesmo hogback, como o de Brompton, sem dúvida, atestam nossa interpretação para uma origem pagã, ao menos para alguns destes monumentos. O arqueólogo Richard Bailey percebeu que a triquetra existente em Brompton seria algo além de mera ornamentação, chegando a comparar o símbolo com o encontrado no carro de Oseberg, Noruega. Mesmo assim, denomina a mesma de "curious symbols" e não realiza maiores esclarecimentos analíticos e religiosos. BAILEY, Richard - Scandinavian myth on viking-period Stone sculpture in England in BARNES, Geraldine \& ROSS, Margaret Clunie (orgs.) - Old Norse myths, literature and society. Proceedings of the $11^{\text {th }}$ International Saga Conference. Sidney: University of Sidney, 2000, p. 17. Já o arqueólogo Richard Hall considera o significado dos ursos presentes nos hogbacks como "incerto". HALL, Richard Exploring the world of the Vikings. London: Thames and Hudson, 2007, p. 106.

41 Lilla Kopár acredita que Gosforth é semelhante às estelas de Gotland, sem estrutura linear ou sequencial. KOPÁR, Lilla - An intercultural dialogue set in Stone. VIN Seminar I: Myth and cultural memory in the Viking Diaspora. Leicester, UK, 2007, p. 8-9.

${ }^{42}$ BAILEY, Richard - Scandinavian myth on viking-period Stone sculpture in England in BARNES, Geraldine \& ROSS, Margaret Clunie (orgs.) - Old Norse myths, literature and society. Proceedings of the $11^{\text {th }}$ International Saga Conference. Sidney: University of Sidney, 2000, p. 10.
} 
de Cristo e a chegada ao Valhalla. O Leste é o ponto onde o sol nasce e possui simbolismos específicos no imaginário cristão, como a representação do galo, emblema da luz e da ressurreição. ${ }^{43}$ Por isso encontramos este animal gravado em cruzes da Ilha de Man, como Grim em Michael, logo acima de Cristo crucificado. ${ }^{44}$

Comparando a relação ambígua entre a mitologia nórdica e cristã no imaginário das ilhas britânicas, podemos ter algumas similitudes e diferenças entre as cruzes de Gosforth e Thorwald. As semelhanças ocorrem no sentido de entender quais tradições e elementos dos mitos escandinavos foram recuperados para dar sentido aos princípios da religiosidade imperante naquelas regiões. A morte de Odin é a principal, sendo retratada de modo objetivo em Thorwald e figurativo em Gosforth (na Face Norte). Na primeira ocorre a representação do ataque de Fenrir, enquanto que na segunda a morte é apenas sugerida pela inversão da imagem do cavaleiro com lança. Mas as diferenças também são muito representativas. Em Thorwald a figura da serpente é fundamental - ela está entrelaçada ao lado de Odin, e do outro lado da cruz, acima e abaixo do missionário. ${ }^{45}$ Em Gosforth não ocorrem representações de serpentes. Neste sentido, houve uma adequação muito maior ao imaginário cristão por parte do escultor da Ilha de Man, que procurou demonstrar a vitória sobre o demônio de forma muito contundente. Já no monumento inglês, o animal destacado é o lobo. Em três faces da cruz ocorrem duplas representações de canídeos, o que reforça a idéia de que nos últimos tempos, algumas das grandes ameaças surgirão na forma de lobos monstruosos, seja no céu - com Hati e Skol devorando o sol e a Lua (imagem também presente no hogback de Tyninghame), e na terra dos deuses e dos homens com a libertação de Garm e Fenrir. Nada mais natural para a mente escandinava, visto que o próprio Odin possuía dois lobos de estimação (representação presente na cruz de Rumund, Michael, Ilha de Man). Mesmo se pensarmos que neste caso o(s) lobo(s) foi destacado para representar a figura do mal, o

\footnotetext{
${ }^{43}$ CHEVALIER, Jean \& GHEERBRANDT, Alain - Galo. Dicionário de símbolos. Rio de Janeiro: José Olympio Editora, 2002, p. 458.

44 KERMODE, P.M.C. - Traces of the norse mythology in the Isle of Man. London: Bemrose \& Sons, 1904, prancha IV, p. 20. O galo também possui importância na tradição nórdica: segundo a Völuspá 43, a estrofe que antecede a sequência do Ragnarök (vv. 44-66), um galo cantará nas salas do reino de Hel.

45 As três representações de serpente na cruz de Thorwald possuem entrelaçamento - talvez sejam uma alusão à serpente do mundo, que estava enrolada sobre a terra dos homens antes de se libertar no Ragnarök. Essa mesma imagem serpentiforme aparece na cruz de Cruz de Sockburn 3A, Durham (ver figura 8), ao lado da figura de Odin e logo acima da imagem de uma valquíria recebendo um guerreiro com corno de hidromel.
} 
conjunto cênico de Gosforth é muito mais próximo da cultura pré-cristã do que o da cruz de Thorwald.

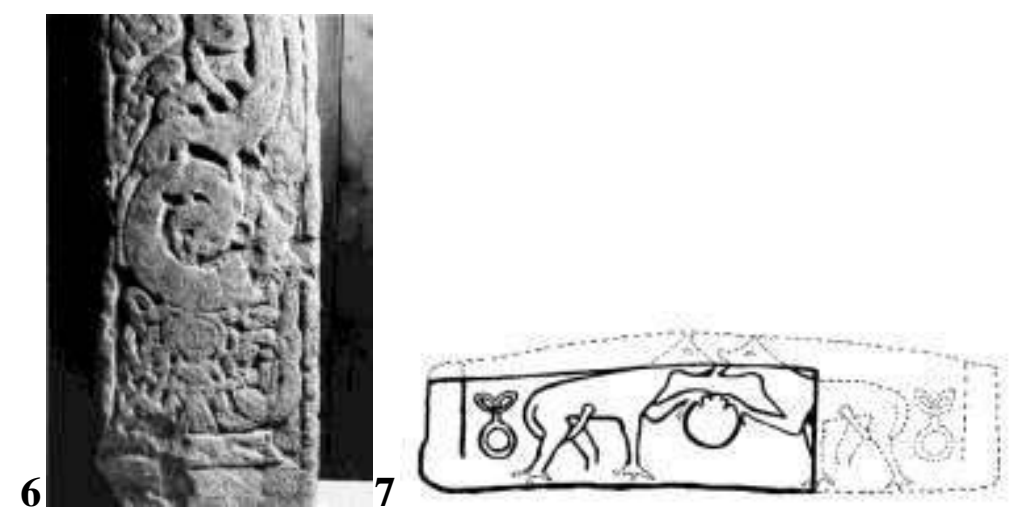

Figura 6: Cruz de Great Clifton 1A, Cumbria, Inglaterra, 930-980 d.C. Fonte: Corpus of AngloSaxon Stone Sculpture: http://www.dur.ac.uk/sculpturecorpus/ Na base da escultura, em meio a várias serpentes, uma figura masculina possui as mãos presas por argolas. Pode se tratar da figura de Loki ou de Gunnar no fosso das serpentes.

Figura 7: Hogback de Tyninghame, East Lothian, Inglaterra, 900-950 d.C. Fonte: Corpus of Anglo-Saxon Stone Sculpture: http://www.dur.ac.uk/sculpturecorpus/ Dois canídeos seguram um disco com as patas, e ao lado de cada um, uma forma circular. Pode se tratar da representação de Hati e Skoll atacando o Sol e a Lua. 


\section{A iconografia do Ragnarok e as fontes literárias}

Neste momento, vamos realizar uma análise geral das fontes iconográficas das ilhas britânicas, comparando-as com os relatos sobre o Ragnarök. Começando pela Völuspá, temos como temas sequenciais (vv. 44-66): o latido e a fuga de Garm; discórdia e morte entre parentes; Heimdall toca seu corno; fuga de Fenrir; a serpente do mundo se desata; Loki foge e avança sobre o mundo com monstros; Surt chega com fogo; Odin é morto por Fenrir; Vithar vinga o pai; Thor mata a serpente do mundo, porém cai envenenado; o Sol se escurece, a terra submerge, as estrelas caem; Balder regressa com Hodr; o salão Gimle passa a ser a nova casa dos deuses; o dragão Nidhogg voa sobre os mortos. ${ }^{46}$

Sem dúvida, o tema que mais aparece representado é o do lobo, seja Garm e Fenrir fugindo de suas prisões (Gosforth 1), Hati e Skol devorando o Sol e a Lua (Hogback de Tyninghame, ver figura 7) ou Fenrir devorando Odin (Andreas 128). Apesar de todas estas cenas não terem sido representadas iconograficamente na área escandinava durante o período pagão, elas refletem objetivamente uma tradição baseado no culto e simbolismo do lobo, sem maiores relações com o cristianismo (ver tabela 2). Discordamos dos acadêmicos que pensam que elas foram associadas à pesca do Leviatã e a Jonas e a Baleia pelo imaginário cristão. ${ }^{47}$ São cenas que possuem um apelo muito grande para povos advindos de regiões onde os animais selvagens ainda tinham grande impacto no cotidiano e na religiosidade. ${ }^{48}$

\footnotetext{
${ }^{46}$ As cenas sublinhadas foram retratadas nos monumentos britânicos do século X. As cenas de Heimdall e seu corno, a morte de Odin por Fenrir e a morte desta besta por Vithar, não foram representadas na área escandinava, mas são citadas em fontes literárias, como a Völuspá, Vafprúðnismál e Gylfaggining.

${ }^{47}$ KOPÁR, Lilla - An intercultural dialogue set in Stone. VIN Seminar I: Myth and cultural memory in the Viking Diaspora. Leicester, UK, 2007, p. 5. Essa associação pode ser verificada pela existência da cena da pesca da serpente do mundo pelo deus Thor (cruz de Gosforth 6, Cumbria, Inglaterra, século X), mas nunca com as representações dos lobos míticos.

${ }^{48} \mathrm{Na}$ Escandinávia da Era Viking, os lobos eram alvos de caças, associados com o mundo selvagem (o epíteto para desterrado era lobo, CHRISTIANSEN, Eric - The norsemen in the Viking Age. London: Blackwell, 2006, p. 33); objeto de culto de guerreiros devotos de Odin, (Úlfhéðnar, os peles de lobos); símbolos dos guerreiros jovens, GRIFFITH, Paddy - The viking art of war. London: Greenhill Books, 1995, p. 135.
} 


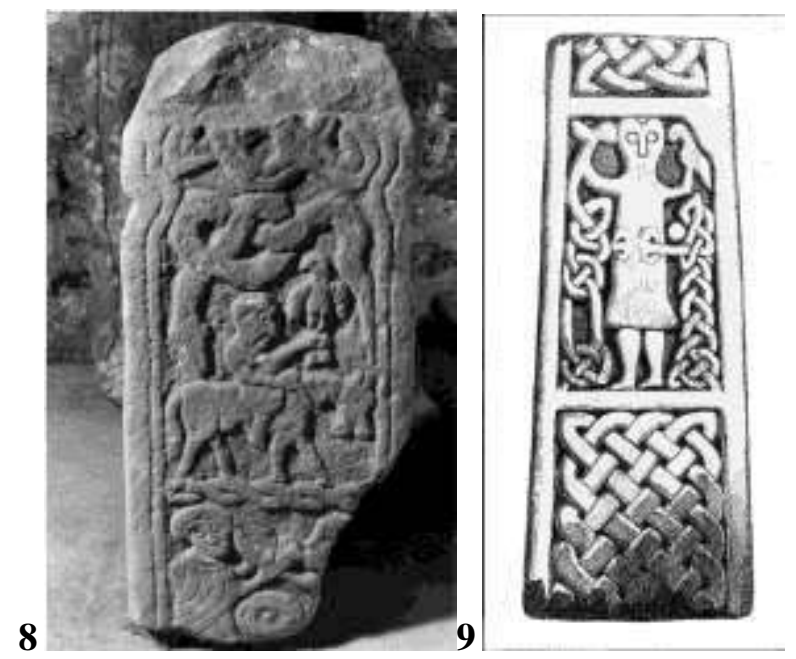

Figura 8: Cruz de Sockburn 3A, Durham, Inglaterra, 920-1000 d.C. Fonte: Corpus of AngloSaxon Stone Sculpture: http://www.dur.ac.uk/sculpturecorpus/ Um cavaleiro porta um pássaro com uma das mãos (Odin e um de seus corvos). Acima deste, uma serpente enrolada (a serpente do mundo?). Logo abaixo, uma mulher entrega um corno de bebida para uma figura masculina (Valquíria).

Figura 9: Cruz de Bilingham 1, Inglaterra, 920-980 d.C. Fonte: Corpus of Anglo-Saxon Stone Sculpture: http://www.dur.ac.uk/sculpturecorpus/ Um homem segura um pássaro (Odin?). Uma de suas mãos e parte do tronco se funde a linhas trançadas lateralmente - um típico simbolismo odínico presente na arte anglo-escandinava: os deuses e homens estão atrelados ao destino.

Uma ausência icônica perceptível são as narrativas do mito de Balder. Sua morte, que na Völuspá (Codex Regius) antecede a sequência do Ragnarök, também não ocorre na versão do Hauksbók e no poema éddico Vafprúðnismál. Nestes dois últimos, o fim dos tempos aparece sem uma motivação objetiva. A ressurreição de Balder, morando com seus filhos no palácio de Gimle, após o Ragnarök, aparece também no Gylfaggining de Snorri Sturlusson, mas é inexistente no Vafprúðnismál - aqui quem herda a terra após a morte dos deuses são Vídar e Vali. Como a Völuspá (versão do Codex Regius) é posterior às cenas da cruz de Gosforth 1 , acreditamos que o seu autor fundiu duas tradições míticas diferentes, a do fim dos tempos e a de Balder, procurando conceder 
maior dinamismo, coerência e semelhança com a mitologia cristã. Balder, neste caso, surge como uma corruptela ou antecessor da figura do Cristo ressurreto.

Neste sentido, concordamos com o pesquisador John Mckinell, que percebe o poema Vafprúđnismál tendo uma estrutura mais próxima da tradição pré-cristã que a Völuspá ${ }^{49}$ - apesar de conter menos detalhes sobre o Ragnarök que as outras fontes literárias, certamente seu sentido é muito mais pagão. Por exemplo, a cena em que Vithar mata o lobo Fenrir destroçando e abrindo sua mandíbula, ocorre em Vafprúđnismál e na face Leste da cruz de Gosforth 1, mas não na Völuspá. Vários pesquisadores já analisaram este episódio do monumento britânico como uma simples similaridade entre filhos de deuses vitoriosos, associando diretamente Vithar a Cristo. ${ }^{50}$ Apesar desta associação ter sido possível na mente do escultor ou patrocinador, nós pensamos outra perspectiva. A morte de Fenrir nas mãos de Vithar representa um dos sentimentos máximos da ideologia guerreira e da própria sociedade pré-cristã: a vingança, especialmente de um ente familiar. ${ }^{51}$ Neste sentido, Gosforth possui os mesmos elementos que constituem a base ideológica de Vafprúonismál: a admiração da força (Odin e Heindamll), da coragem (Týr com a mão na boca de Fenrir), da resistência e da vingança justificada (Vithar matando Fenrir).

A proximidade do escandinavo pagão com uma nova realidade cultural e religiosa - o mundo celta e anglo-saxão cristianizado, o levou a reelaborar e selecionar elementos de sua mitologia que antes não tinham tanta relevância social e iconográfica (ver tabelas 1 e 2). A chegada do ano mil iria definir novos parâmetros para a iconografia dos mitos nórdicos, especialmente os relacionados ao Ragnarök.

A aproximação com a figura de Satã - antes secundária e com elementos mal definidos no imaginário, mas que a partir do século X ganha perfil central e mais freqüente na arte

\footnotetext{
${ }^{49}$ MCKINELL, John - Both one and on many: essays on change and variety in late norse heathenism. Roma: Il Calamo, 1994, p. 107-128.

${ }^{50}$ KOPÁR, Lilla - An intercultural dialogue set in Stone. VIN Seminar I: Myth and cultural memory in the Viking Diaspora. Leicester, UK, 2007, p. 5.

51 A respeito das formas de violência e vingança entre as comunidades da Era Viking, o caso mais tradicional era o da Islândia: "Icelandic blood feud was a form of vengeance-taking. It involved deep, smouldering animosities leading to repeated reprisals. Score was kept of injuries and killings inflicted on enemies. The taking of vengeance was understood as action that satisfied honour, and exchanges of violence could go on for a very long time, frequently over generations". BYOCK, Jesse - Viking Age Iceland. London: Penguin Books, 2001, p. 208.
} 
cristã $^{52}$ - faz com que o personagem Loki seja dimensionado em uma nova importância. Se antes ele não era relevante para a imagética guerreira - totalmente ausente nas estelas de Gotland - agora ele se torna um dos arautos do fim dos tempos, na forma do mal preso que deve em breve se libertar. Apesar de presente em Gosforth 1 e Great Clifton 1A (ver figura 6), é em Kirby Stephen 1A que sua forma se torna ainda mais próxima de Satã: um ser barbado, com as mãos e pernas presas e um par de chifres (inexistente na mitologia original). ${ }^{53}$ Aliás, essa idéia do mal preso, prestes a se libertar, também figura em outro tema relacionados ao Ragnarök: o lobo Fenrir no hogback de Sockburn é um dos vários canídeos com as pernas presas sob argolas e correntes de forma muito semelhante as de Loki. O medo e as angústias coletivas do ano mil, as concepções otimistas dos milenaristas, as pessimistas dos apocalípticos e as inúmeras versões bíblicas do fím dos tempos que cercavam a véspera do ano mil ${ }^{54}$ certamente influenciaram as visões de mundo dos anglo-escandinavos.

Existem ainda muitas questões, vários desafios interpretativos e diversas fontes iconográficas e literárias a serem analisadas. A relação entre texto e imagem na Alta Idade Média ainda é pouco investigada pelos historiadores. ${ }^{55}$ Nesta nossa pequena incursão a estes limites, alguns pontos ficaram bem claros: um deles, que a morte de Odin fazia parte das concepções originais do paganismo, assim como a maioria dos episódios ligados ao Ragnarök. Sofrendo transformações estruturais a medida que os escandinavos iam sendo cristianizados, as idéias sobre o fim dos deuses foram dando continuidade à tradição oral e imagética pagã, mas aos poucos transformaram-se pelo hibridismo cultural, já não sendo tanto pagãs, mas também, em alguns casos, nem tanto cristãs. Se a cruz de Thorwald pode transmitir uma idéia mais objetiva do triunfo cristão, isso não é detectado na cruz de Gosforth, que transita entre dois mundos de

\footnotetext{
52 A partir do ano 1000 o diabo ganha feições monstruosas e animalescas no imaginário "e manifestando seu poder hostil de modo cada vez mais insistente". BASCHET, Jérôme - Diabo in LE GOFF, Jacques \& SCHMITT, Jean-Claude (orgs.) - Dicionário temático do Ocidente Medieval. São Paulo: Edusc, 2002, p. 320.

53 Apesar desta representação bestial, a arte das ilhas britânicas ainda preservou a imagem original de Loki, próxima do trickster dos mitos indígenas: prestes a atirar uma pedra em Otter (Maughold 122, Ramsey, Ilha de Man).

${ }^{54}$ FRANCO JÚNIOR, Hilário - O ano 1000: tempo de medo ou de esperança? São Paulo: Companhia das Letras, 1999, p. 40, 84-85.

${ }^{55}$ Um excelente exemplo de estudo sobre a relação entre texto (poesia anglo-saxônica: "O sonho da cruz") e imagem (a cruz de Ruthwell) na Inglaterra alto-medieval é promovido por: SCHMITT, JeanClaude - A legitimação das novas imagens em torno do ano mil. O corpo das imagens: ensaios sobre a cultura visual na Idade Média. São Paulo: Edusc, 2007, p. 165-174.
} 
forma complementar e harmônica. Se alguns estudiosos podem hoje afirmar que a Völuspá foi produto de um poeta pagão que foi influenciado pela cultura cristã, nosso estudo nos leva a considerar que muitos hogbacks e cruzes da área britânica foram produzidos por pagãos ou semi-convertidos que criaram uma nova identidade para as antigas narrativas de deuses que possuem uma finitude. Dentro das várias transformações em que a sociedade medieval estava passando na virada do século IX para o X, certamente as narrativas do Ragnarök ao menos trouxeram conforto a guerreiros vivendo em um novo mundo. Pois uma das funções básicas do mito é conceder respostas às inquietudes do cotidiano, ao mesmo tempo em que se transforma junto com a dinâmica cultural. ${ }^{56}$ Com o passar dos anos, o fim dos deuses já não possuirá a importância dos tempos de conversão, mas não devemos nos iludir quanto a sobrevivência de seus simbolismos: em uma pequena igreja do interior da Inglaterra (St. Mary, Canfield, Essex), no século XII, um escultor habilmente elaborou acima de uma coluna, a deidade maior dos escandinavos, ladeado com seus dois corvos e várias suásticas. Os tempos já eram normandos e totalmente cristãos, mas Odin ainda fazia parte da vida dos homens.

\footnotetext{
56 “(...) todo mito procura fundamentalmente responder a uma certa inquietação sociopsicológica (...) O mito desangustia e ensina porque é um relato sagrado ou ao menos sobre o sagrado, e é um relato sagrado porque acalma a angústia do viver, porque explica o até então incompreensível”. FRANCO JÚNIOR, Hilário - A Eva barbada: ensaios de mitologia medieval. São Paulo: Edusp, 1996, p. 22, 67.
} 
Tabela 1: Temas iconográficos da mitologia nórdica comuns à área britânica e escandinava (séc. X) $)^{57}$

\begin{tabular}{|c|c|c|}
\hline Tema/cena & Fonte & Local \\
\hline $\begin{array}{l}\text { Týr com a mão na boca } \\
\text { de Fenrir }\end{array}$ & $\begin{array}{l}\text { Hogback de Sockburn 21AC, Durham } \\
\text { Bloco de Forcett } 4 \text {, Northern Yorkshire }\end{array}$ & $\begin{array}{l}\text { Inglaterra } \\
\text { Inglaterra }\end{array}$ \\
\hline Odin & $\begin{array}{l}\text { Hogback de Lowther 5C, Cumbria } \\
\text { Hogback de Saint's Tomb, Kirke }\end{array}$ & $\begin{array}{l}\text { Inglaterra } \\
\text { Inglaterra }\end{array}$ \\
\hline Odin e um corvo & $\begin{array}{l}\text { Cruz de Sockburn 3A, Durham } \\
\text { Cruz de Bilingham } 1\end{array}$ & $\begin{array}{l}\text { Inglaterra } \\
\text { Inglaterra }\end{array}$ \\
\hline $\begin{array}{l}\text { Odin sendo devorado } \\
\text { pelo lobo Fenrir }\end{array}$ & $\begin{array}{l}\text { Fragmento de cruz de Thorwald, Kirk } \\
\text { Andreas } 128 \\
\text { Grafite de Skipwith 1, Eastern Yorkshire }\end{array}$ & $\begin{array}{l}\text { Ilha de Man } \\
\text { Inglaterra }\end{array}$ \\
\hline Odin e dois corvos & $\begin{array}{c}\text { Cruz da igreja de St. Martin, Kirklevington, } \\
\text { North Yorkshire }\end{array}$ & Inglaterra \\
\hline $\begin{array}{l}\text { Homem lutando com } \\
\text { serpente (Sigurd?) }\end{array}$ & Hogback da Igreja de St. Mary & Inglaterra \\
\hline Valquíria & $\begin{array}{c}\text { Cruz com runas de Jurby } 125 \\
\text { Hogback de Sockburn 15A, Durham } \\
\text { Cruz de Gosforth } 1 \\
\text { Fragmento de cruz de Michael } \\
\text { Cruz de Sockburn } 3 A \text {, Durham }\end{array}$ & $\begin{array}{l}\text { Ilha de Man } \\
\text { Inglaterra } \\
\text { Inglaterra } \\
\text { Inglaterra } \\
\text { Inglaterra }\end{array}$ \\
\hline Sigurd & $\begin{array}{c}\text { Hogback de York Minster 46, York } \\
\text { Cruz de Halton, Lancashire } \\
\text { Cruz de Nunburnholme 1a-b, Eastern } \\
\text { Yorkshire } \\
\text { Cruz de Kirby Hill 2A, Northern Yorkshire } \\
\text { Fragmento de sepultura Kirby Hill 9, } \\
\text { Northern Yorkshire } \\
\text { Cruz de Ripon, Northern Yorkshire } \\
\text { Sepultura de York Minster 34D, York }\end{array}$ & $\begin{array}{l}\text { Inglaterra } \\
\text { Inglaterra } \\
\text { Inglaterra } \\
\text { Inglaterra } \\
\text { Inglaterra } \\
\text { Inglaterra } \\
\text { Inglaterra }\end{array}$ \\
\hline $\begin{array}{l}\text { Sigurd assando o } \\
\text { coração de Fáfnir }\end{array}$ & $\begin{array}{c}\text { Cruz de Andreas } \\
\text { Fragmento de cruz de Malew }\end{array}$ & $\begin{array}{l}\text { Ilha de Man } \\
\text { Ilha de Man }\end{array}$ \\
\hline Sigurd matando Fáfnir & $\begin{array}{l}\text { Fragmento de cruz de Jurby } 119 \\
\text { Fragmento de cruz de Malew } 120\end{array}$ & Ilha de Man \\
\hline $\begin{array}{l}\text { Gunnar no fosso das } \\
\text { serpentes }\end{array}$ & Fragmento de cruz de Andreas 121 & Ilha de Man \\
\hline $\begin{array}{c}\text { Vollundr na forja ao lado } \\
\text { de seu filho } \\
\text { descabeçado }\end{array}$ & Cruz de Halton & Inglaterra \\
\hline $\begin{array}{l}\text { Thor pescando a } \\
\text { serpente do mundo }\end{array}$ & $\begin{array}{c}\text { Fragmento de cruz de Gosforth 6, } \\
\text { Cumbria }\end{array}$ & Inglaterra \\
\hline Weland & Cruz de Brompton 3A, Northern Yorkshire & Inglaterra \\
\hline
\end{tabular}

${ }^{57}$ A maioria das imagens da área britânica está disponível online pela Universidade de Durham, Corpus of Anglo-Saxon Stone Sculpture: http://www.dur.ac.uk/sculpturecorpus/ 
Tabela 2: Temas iconográficos da mitologia nórdica exclusivos da área britânica (séc. $\mathrm{X})$

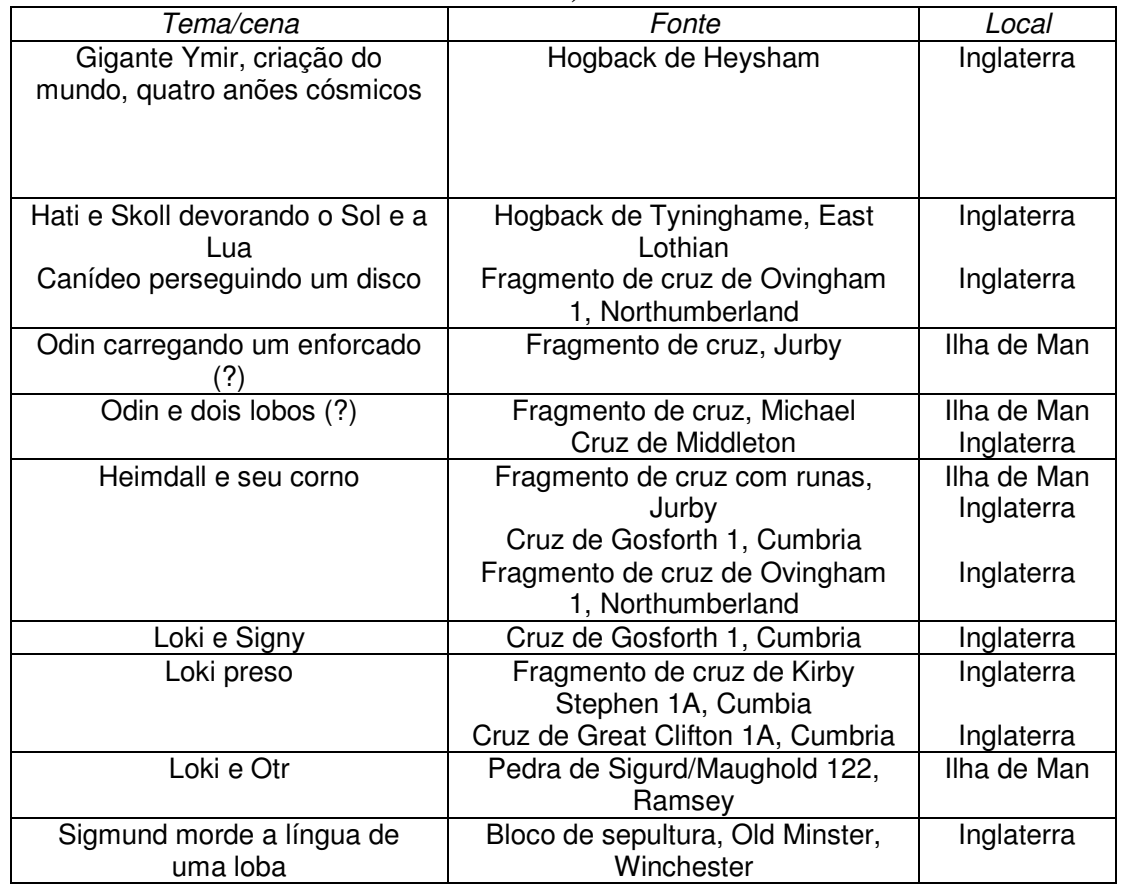




\section{Bibliografia:}

\section{Fontes primárias:}

ANÔNIMO - Völuspá (Codex Regius, Hauksbók, Snorra Edda), Vafprúðnismál edição de Sophus Bugge: Sæmundar Edda, 1867, disponível em: Old Norse etexts, http://etext.old.no/ Traduções ao inglês: The Poetic Edda, edição de Lee Hollander. Texas: University of Texas Press, 2008; STURLUSON, Snorri - The Prose Edda, edição de Jesse Byock. London: Penguin Books, 2005.

\section{Fontes secundárias:}

BAILEY, Richard - Scandinavian myth on viking-period Stone sculpture in England. in BARNES, Geraldine \& ROSS, Margaret Clunie (orgs.) - Old Norse myths, literature and society. Proceedings of the $11^{\text {th }}$ International Saga Conference. Sidney: University of Sidney, 2000, pp. 15-23.

BOYER, Régis - Ragnarök. Héros et dieux du Nord: guide iconographique. Paris: Flammarion, 1997.

BOYER, Régis - Yggdrasill: La religion des anciens scandinaves. Paris: Payot, 1981.

CHRISTIANSEN, Eric - The norsemen in the Viking Age. London: Blackwell, 2006.

DAVIDSON, Hilda - Myths and symbols in Pagan Europe: early Scandinavian and celtic religions. London: Syracuse Press, 1988.

FRANCO JÚNIOR, Hilário - O ano 1000: tempo de medo ou de esperança? São Paulo: Companhia das Letras, 1999.

FUGLESANG, Signe Horne - Iconographic traditions and models in Scandinavian imagery in BARNES, Geraldine \& ROSS, Margaret Clunie (orgs.) - Old Norse myths, literature and society. Proceedings of the $11^{\text {th }}$ International Saga Conference. Sidney: University of Sidney, 2000, pp. 1-11. 
GRIFFITH, Paddy - The viking art of war. London: Greenhill Books, 1995.

HALL, Richard - Viking Age Archaeology in Britain and Ireland. London: Shire Publications, 2010.

KERMODE, P.M.C. - Traces of the norse mythology in the Isle of Man. London: Bemrose \& Sons, 1904.

KOPÁR, Lilla - An intercultural dialogue set in Stone. VIN Seminar I: Myth and cultural memory in the Viking Diaspora. Leicester, UK, 2007, pp. 1-14.

LAPIDGE, Michael (org.) - The Blacwell Encyclopaedia of Anglo-Saxon England. London: Blacwell, 2001.

LANG, J. T. - Anglo-scandinavian sculpture in Yorkshire in HALL, Richard (ed.). Viking Age and the North. London: Council for British Archaeology, 1978, pp. 11-20.

LANGER, Johnni - Símbolos religiosos dos vikings: guia iconográfico. História, imagem e narrativas 11, 2010, pp. 1-28.

LANGER, Johnni - Deuses, monstros, heróis: ensaios de mitologia e religião viking. Brasília: Editora da Universidade de Brasília, 2009.

LANGER, Johnni - As estelas de Gotland e as fontes iconográficas da mitologia viking. Brathair 6, 2006, pp. 10-41.

LINDOW, John \& CLOVER, Carol (orgs.) - Old Norse icelandic literature: a critical guide. Toronto: University of Toronto, 2005.

MCKINELL, John - Völuspá and the feast of Easter. Alvíssmál 12, 2008, pp. 3-28.

MCKINELL, John - Both one and on many: essays on change and variety in late norse heathenism. Roma: Il Calamo, 1994.

MCTURK, Rory (ed) - A company to Old Norse-Icelandic Literature and culture. London: Blackwell Publishing, 2007.

NORDAL, Sigurður - Three essays on Völuspá. Saga-book 3 (18), 1972, p. 79-91. 
PULSIANO, Philip \& WOLF, Kirsten (Eds.) - Medieval Scandinavia: an encyclopedia. London: Routledge, 1993.

RUSSELL, James - The germanization of early medieval Christianity: a sociohistorical approach to religious transformation. Oxford: Oxford University Press, 1994.

SEABORNE, Malcolm - Celtic crosses of Britain and Ireland. Oxford: Shire Publications, 1994.

SØRENSEN, Preben Meulengracht - Religions Old and New in SAWYER, Peter (org.) - The Oxford Ilustrated History of the Vikings. Oxford: Oxford University Press, 1997.

STONE, Alby - Hogbacks: Christian and pagan imagery on Viking Age monuments. $3^{\text {rd }}$ Stone 33, January-march 1999, pp. 16-20.

WILSON, David - Manx memorial Stones of the Viking Period. Saga-Book 18, 19701971, p. 1-18.

WÜRTH, Stefanie - Ragnarök: Götterdämmerung und Weltende in der nordischen Literatur in ROSS, Margaret Clunies \& BARNES, Geraldine. Old Norse Myths, literature and society. Sydney: University of Sydney, 2000, pp. 580-589. 


\section{COMO CITAR ESTE ARTIGO}

\section{Referência electrónica:}

LANGER, Johni - "A morte de Odin? As representações do Ragnarok na arte das Ilhas

Britânicas (séc. X)”. Medievalista [Em linha]. Nº11, (Janeiro - Junho 2012).

[Consultado dd.mm.aaaa]. Disponível em

http://www2.fcsh.unl.pt/iem/medievalista/MEDIEVALISTA11Vlanger1108.html.

ISSN 1646-740X.

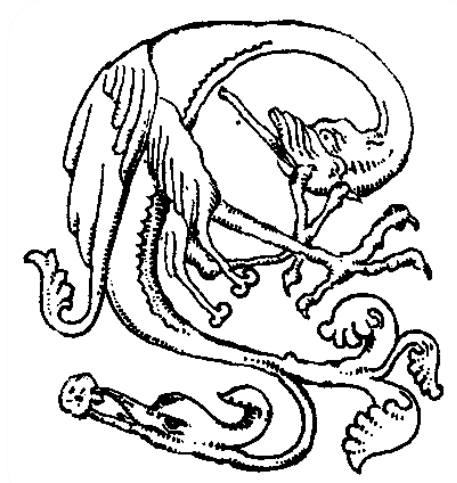

